\title{
Aydınlatılmış kent parklarının kullanıcılar tarafından değerlendirilmesi: Meydan parkı ve Atapark örnekleri
}

\section{Evaluation of illuminated city parks by users: Meydan park and Atapark examples}

\author{
Banu Çiçek KURDOĞLU ${ }^{1}$, Tuğba ÜSTÜN TOPAL ${ }^{2}$ \\ ${ }^{1}$ Karadeniz Teknik Üniversitesi, Orman Fakültesi, Peyzaj Mimarlığı Bölümü, Trabzon, Türkiye \\ ${ }^{2}$ Namık Kemal Üniversitesi, Güzel Sanatlar Tasarım ve Mimarlık Fakültesi, Peyzaj Mimarlığı Bölümü, Tekirdağ, Türkiye
}

\section{Eser Bilgisi / Article Info \\ Araştırma makalesi / Research article \\ DOI: $10.17474 /$ artvinofd.289510 \\ Sorumlu yazar / Corresponding author \\ Tuğba ÜSTÜN TOPAL \\ e-mail: tustun@nku.edu.tr \\ ORCID: 0000-0002-9687-927X \\ Geliş tarihi / Received \\ 03.02.2017 \\ Düzeltme tarihi / Received in revised form \\ 08.09.2017 \\ Elektronik erişim / Online available \\ 14.09.2017}

Anahtar kelimeler:

Aydınlatma

Kent parkı

Anket

Meydan Parkı

Atapark

Trabzon

Keywords:

Lighting

Urban park

Questionnaire

Meydan Park

Atapark

Trabzon

\begin{abstract}
Özet
Bu çalışma ile kentsel park alanlarında yapılan aydınlatmaların kullanıcı üzerindeki etkileri ile kullanııların aydınlatmayı beğenisi ve tercihlerini sorgulamak, mevcut tasarımın estetik olarak kullanıılar üzerinde yarattığı etkiyi irdelemek amaçlanmıştır. Bu doğrultuda kullanılma ilkeleri, kentteki konumları, erişilebilirlikleri ve sahip oldukları nitelikler bakımından benzer sayılabilecek özelliklere sahip olan ancak, kullanılan aydınlatma tip ve teknikleri açısından geleneksel ve modern olmak üzere iki farkıı yaklaşımın görüldüğü iki kent parkı çalışma alanı olarak seçilmiştir. Bu amaç doğrultusunda, her iki parkın da kendi kullanıcılarına aydınlatma tasarımı ile ilgili hazırlanan anket çalışması uygulanmıştır. Ankette öncelikle kullanıcıları tanımaya ve kullanımları belirlemeye yönelik sorular sorulduktan sonra her iki parkın aydınlatılmış mekân bileşen ve öğelerinin (yaya yolları ve merdivenler, oturma alanları vb.) kullanıcılar tarafından anlamsal açıdan değerlendirilmesi için "anlamsal farklılaşım ölçeği” kullanılmıştır. Verilerin istatistik analizleri sonucunda Meydan Parkı'nın \%75, Atapark'ın \%76 güvenli bulunduğu, mekân bileşen ve öğelerinden oturma alanlarının her iki park için sırasıyla 3.46, 3.21 değerleriyle güven verici; 3.38, 3.34 ile dinlendirici; 3.25, 3.04 ile hareketli; su elemanlarının 3.68, 3.60 ile güven verici; bitkisel elemanların da 3.13, 3.02 ile güven verici, 3.04, 3.12 ile etkili, 3.19, 3.09 ile ferahlatıcı olarak nitelendirdiği görülmüştür. Bu sonuçlar ile Meydan Parkı ve Atapark'ın aydınlatma tip ve teknikleri açısından farklılıklar göstermesine karşın, bu durumun aydınlatmanın güvenlik, estetik ve ekonomik yönden sağladığı katkılar açısından büyük farklıııklara sebep olmadığı, benzer şekilde kullanıcılarının aydınlatma ile ilgili beğeni ve tercihlerinde de büyük farklılıklar olmadığı ortaya konulmuştur.
\end{abstract}

\begin{abstract}
With this study, it is aimed to investigate the effects of illumination in urban park areas on the user, inquire about liking and preferences of the users about illumination and examine the aesthetic effect of the current design on users. In this respect, two urban parks were chosen as the study area which have similar characteristics in terms of their usage principles, their location, accessibility and qualities in the city, but with two different approaches: traditional and modern, in terms of lighting types and techniques used. For this purpose, a questionnaire which prepared about lighting design was applied to their own users of both parks. After asking questions to identify users and determine their usage, "Semantic differentiation scale" was used for the semantic assessment of illuminated place components and elements of the two parks (pedestrian paths and ladders, seating areas, etc.) by the users. As a result of the statistical analysis of the data, it was seen that $75 \%$ of Meydan Park and $76 \%$ of Atapark are safe, place components and elements respectively for both parks, seating areas are reassuring with values of $3.46,3.21$; resting with 3.38 , 3.34; moving with 3.25 , 3.04; water elements reassuring with 3.68, 3.60; herbal elements were reassuring with 3.13 , 3.02, effective with $3.04,3.12$, refreshing with 3.19, 3.09. These results show that although Meydan Park and Atapark differ in terms of lighting types and techniques, this does not cause great differences in terms of contribution from the security, aesthetics and economics, and similarly there is no big difference in users' liking and preferences related to lighting.
\end{abstract}

\section{Giriş}

Aydınlatma kişilerin görme ihtiyaçlarına cevap verme gayesi ile birlikte, ekonomiyi gözeterek görme konforunu ve iş verimini yükseltmeyi, mimarlıkta hacim ve yüzeylerin mimari özelliklerini vurgulamayı amaç edinen bir tekniktir (Büyükbıçakçı 2010).

Kentsel aydınlatma ise, bölge ve kent ölçeğinde, çeşitli kent öğeleri ve önemli işlevsel alanlar gibi kentin önemli parçalarının aydınlatılmasını kapsamaktadır (Sözen ve 
Geçioğlu 2007; Öztürk 1992). Kentlerin ve/veya değişik kent bölgelerinin kimliklerini ortaya çıkarmak, belleklerde yer etmesini sağlamak, değişik etkilerle çekici kılmak gibi amaçlarla aydınlatılmaları oldukça önemlidir (Sözen ve Geçioğlu 2007). Sözen (2000)'e göre kent aydınlatmasındaki başlıca amaçlar; emniyet ve güvenlik sağlanması, çevreyi tanımak, yol-yön-yer bulmak, açık hava etkinliklerinin gerçekleştirilmesi, kent kimliği oluşturma ve kent güzelleştirmedir. Nitekim Onuk (2008) da kentlerin kendi kimliklerini sergilemeleri açısından çeşitli konularda aydınlatılma yapılmasının altını çizmiş ve bunlardan birinin de park ve bahçeler olduğunu belirtmiş̧ir.

Kentlerde gündüz olduğu gibi, gece de yaşamın sürdürülebilmesi için gerekli aydınlığın sağlanmasında yapay ışı kaynaklarından yararlanılmaktadır. Kent yaşamına pozitif katkılar sağlayan kent parçalarından park alanlarının, gece gündüz faydalanma sürelerinin artması, kent imajı ve kent kimliği olgularına nitelik kazandırması, emniyet, güvenlik, kullanılabilirlik ve estetik amaçlar için aydınlatılmasına park aydınlatması denir (Üstün 2014).

Yapay ışık kaynakları kullanılarak gece yapılan aydınlatma düzenleri ile insanlar, gündüz dikkat etmedikleri, hatta farkına bile varmadıkları pek çok kent bölümünü, kentsel değerleri ve yapıları kolaylıkla algılayabilmektedir. Yani, uygun aydınlatma düzenleri kurulmuş kentlerin gece görünümleri, gündüze oranla çok daha ilgi çekici, gizemli ve görkemli olabilmektedir. Bu nedenle, kentlerin gece aydınlatması, güvenlik dışında kentsel görünümlerin etkili kılınması bakımından da büyük önem taşımaktadır (Anonim 1992).

$\mathrm{Bu}$ çalışmada kentsel park alanlarında yapılan aydınlatmaların kullanıcı üzerindeki etkileri ile kullanıcıların aydınlatmayı beğenisi ve tercihlerini sorgulamak, mevcut tasarımın estetik olarak kullanıcılar üzerinde yarattığı etkiyi irdelemek amaçlanmıştır. Bu bağlamda çalışma kapsamında aynı ulaşım aksı üzerinde bulunan iki park olan Meydan Parkı ve Atapark çalışma alanı olarak seçilmiştir. Bu iki parktan Meydan Parkı günümüz teknolojisine uygun son aydınlatma tip ve teknikleri kullanılarak aydınlatılırken, Atapark daha eski tip ve tekniklere sahiptir. Çalışmada bu farkın aydınlatmanın güvenlik, estetik ve ekonomik işlevleri yönünden de farka neden olup olmadığı ortaya konmaktadır.

\section{MATERYAL ve YÖNTEM}

Çalışmanın materyalini oluşturan Meydan Parkı ve Atapark, Trabzon kent merkezinde bulunan ve tarih boyunca planlanma ve kullanılma ilkeleri değişmeden süregelmiş parklardır. Kentteki konum, erişilebilirlik ve sahip oldukları nitelikler bakımından benzer sayılabilecek özelliklere sahiptirler. Sahip oldukları özelliklerin benzerliği dolayısıyla dabu parklardaki mevcut aydınlatmanın kullanıcılar üzerindeki etkilerinin karşılaştırılabilmesi olanağını sunmaktadırlar. Genel olarak ele alındığında, Meydan Parkı yapısal ve bitkisel tasarım özellikleri ve aydınlatma tasarımı açısından daha modern tip ve tekniklerle tasarlanmıştır. Atapark'ta ise daha geleneksel bir tasarım söz konusudur. Çalışma alanlarının kentteki konumu Şekil 1'de,her iki parkın aydınlatılmış haline ilişkin görseller ise şekil 2'de verilmiştir.

Çalışma alanlarından Meydan Parkı'nın sınırlarını batıda Gazipaşa Caddesi, kuzeyde İskele Caddesi, güneyde Uzun Sokak oluşturur. Meydan Parkı'nın doğu sınırında eski belediye binası ve ticari amaçla kullanılan diğer yapısal elemanlar bulunur. Atapark'ı ise doğuda Şenol Güneş Caddesi, batıda Lütfullah Sokak, kuzeyde İnönü Caddesi ve güneyde İnönü Caddesi (Tanjant Caddesi) sınırlar. 


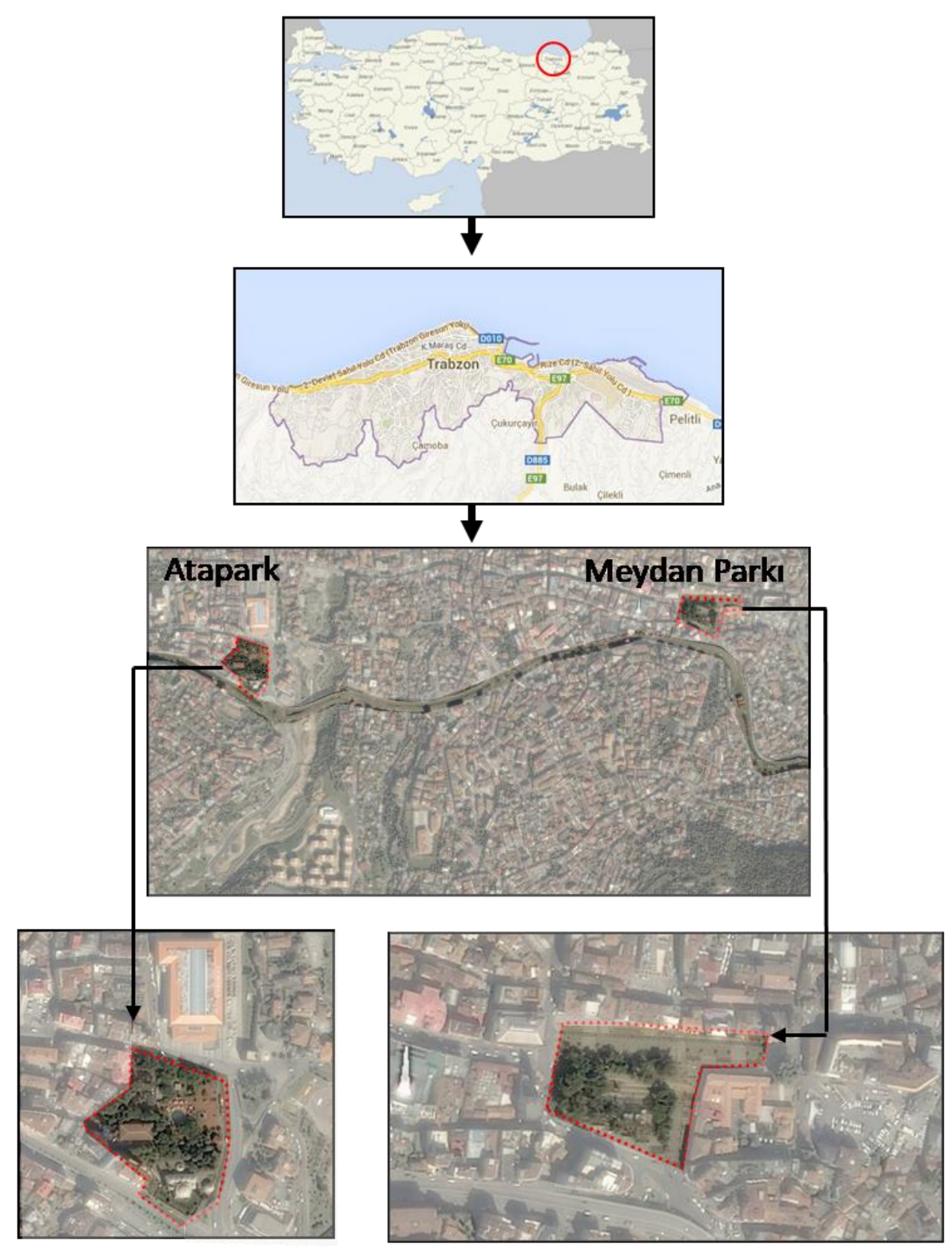

Şekil 1. Çalışma alanları olan Atapark ve Meydan Parkı'nın konumu 

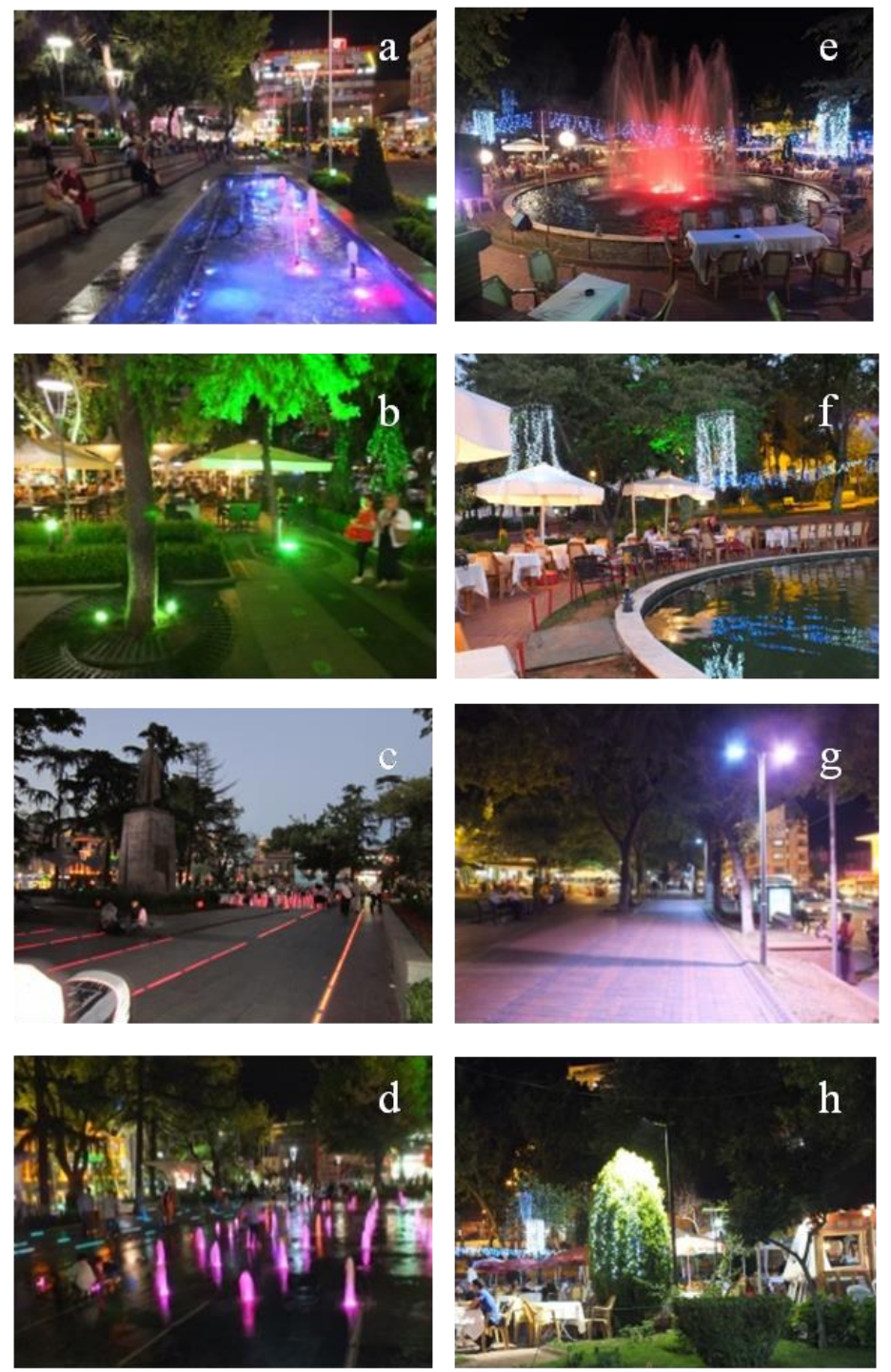

Şekil 2. Meydan Parkı (a, b, c, d) ve Atapark'tan (e,f, g, h) bazı görünümler (Orijinal).

Çalışma kapsamında, halkın katılımının sağlanması ile çalışma alanlarındaki mevcut aydınlatma sistemlerinin kullanıcı tarafından değerlendirilmesi, kullanıcı beğeni ve tercihlerinin belirlenmesi amacıyla, bu parklardaki aydınlatma sistemlerini özellikle görerek deneyimlemiş kişilere anket çalışması uygulanmıştır. Anket soruları hazırlanırken soruların açık ve anlaşılabilir olmasına dikkat edilmiştir. Anket sorularının hazırlanmasında Albayrak (2000), Dedeoğlu (2006), Çetindağ (2007) ve Acar (2008)'ın çalışmalarından faydalanılmıştır. Anket sayısının belirlenmesinde ise, anketlerin yapıldığı 2013 yılına ait Trabzon merkez ilçe nüfusu baz alınarak aşağıdaki formül kullanılmıştır (Kalıpsız, 1981).

$n=\frac{\mathrm{Z}^{2} \mathrm{NPQ}}{\mathrm{ND}^{2}+\mathrm{Z}^{2} \mathrm{PQ}}$ $\mathrm{n}=$ Örnek büyüklüğü

$\mathrm{Z}=$ Güven katsayısı

$\mathrm{P}=$ Ölçmek istediğiniz özelliğin kütlede bulunma ihtimali

$\mathrm{Q}=1-\mathrm{P}$

$\mathrm{N}=$ Ana kütle büyüklüğü

$D=$ Hata yüzdesi

Trabzon merkez ilçe nüfusu dikkate alınarak kent halkına uygulanan bu anketin; \%95 güven aralığında gerçekleştiği tahmin edilerek;

$$
\begin{aligned}
& Z=1,96 \\
& P=0,95 \text { (çalışmada \%95 olarak alınmıştır) } \\
& Q=0,05 \\
& N=312060 \\
& D=0,05
\end{aligned}
$$


$n=\frac{1,96^{2} \times 312060 \times 0,95 \times 0,05}{312060 \times 0,05^{2}+1,96^{2} \times 0,95 \times 0,05}$

$n=73$

Formüle göre çıkan sonuç 73 olmasına rağmen, çalışmanın daha sağlıklı bir sonuç vermesi amacıyla 100 Meydan Parkı kullanıcısı ve 100 Atapark kullanıcısı olmak üzere toplam 200 kişi ile anket yapılmıştır. Anketler, yüz yüze (bire bir) görüşme tekniği ile uygulanmıştır. Anket soruları kullanıcıları tanımaya, kullanımları belirlemeye ve beğenileri sorgulamaya yönelik olmak üzere hazırlanmıştır. Anket formunda kullanıcıları tanımaya ve kullanımları belirlemeye yönelik sorular sorulduktan sonra, anketörlerden aydınlatılmış mekân bileşen ve öğelerinin (yaya yolları ve merdivenler, oturma alanları vb.) değerlendirilmesi için anket cetveli üzerindeki 'sıkıcıilginç', 'tedirgin edici-güven verici', 'yorucu-dinlendirici', 'etkisiz-etkili', 'iç karartıcı-ferahlatıcı', 'estetik değilestetik' ve 'durağan-hareketli' olmak üzere 7 sıfat çiftine $1,2,3,4,5$ puanlarından birini vererek "anlamsal farklılaşım ölçeğine" göre değerlendirmeleri istenmiştir (Çizelge 1). Böylece, Meydan Parkı ve Atapark'ın, aydınlatma tip ve teknikleri açısından farklılıklar göstermesinin, aydınlatmanın güvenlik, estetik ve ekonomik yönünden farklılıklara sebep olup olmadığı, kullanıcılarının aydınlatma yönündeki beğeni ve tercihlerinin nasıl olduğu ortaya konmak istenmiştir.

Ayrıca anket; kullanıcılara 'Yaya yolu ve merdivenlerin', 'Oturma alanlarının', 'Yapı çevrelerinin', 'Çocuk oyun alanlarının', 'Su elemanlarının', 'Anıt, heykel, tarihi eserler ve plastik objelerin' ve 'Bitkisel materyalin' aydınlatmasını görsel olarak hatırlatmak ve alan sınırlarını net olarak algılatmak için 3 'er adet gece görüntüsüyle desteklenmiştir.

Osgood vd. (1975) tarafından geliştirilen anlamsal farklılaşım ölçeği, çevresel psikoloji alanında kullanılan yaygın bir yöntem olup çevre ile gözlemci arasındaki etkileşimi ölçmek, öznel ve çevresel reaksiyonları incelemek amacıyla faydalanılan bir yöntemdir (Sakıcı ve Var, 2014; Acar vd. 2003). Kwok (1979)'a göre belirli duyguları, tutumları ve belirli kavramlarla ilgili davranışları ölçmektedir (Sakıcı ve Var, 2014).

\section{BULGULAR}

Ankete katılan Meydan Parkı kullanıcıları için 100 ve Atapark kullanıcıları için 100 kişinin demografik yapısını gösteren sonuçlar Çizelge 2'de verilmiştir.

Anket katılımcılarına "Meydan Parkı/Atapark'a geliş mesafeleri" sorulduğunda; 'Yürüyüş mesafesinde değil araçla' cevabı Meydan Parkı için \%56 ve Atapark için \%49 ile en yüksek yüzdeye sahip olmuştur (Şekil 3). Sonuçlara bakıldığında Meydan Parkı ve Atapark için verilen tüm cevaplara ait yüzde değerlerinin birbirine çok yakın olduğu görülmektedir. Kullanıcılarının parklara geliş tercihlerine ait sonuçların yakınlığı, parkların kent içerisindeki konumları itibariyle erişilebilirlikleri açısından benzerliğini kanıtlamaktadır.

Çizelge 1. Anlamsal farklılaşım ölçeği

\begin{tabular}{lccccrr}
\hline SIFATLAR & -2 & -1 & Nötr 0 & +1 & +2 & SIFATLAR \\
\hline SIkıcı & 1 & 2 & 3 & 4 & 5 & Ilginç \\
Tedirgin Edici & 1 & 2 & 3 & 4 & 5 & Güven Verici \\
Yorucu & 1 & 2 & 3 & 4 & 5 & Dinlendirici \\
Etkisiz & 1 & 2 & 3 & 4 & 5 & Etkili \\
İ̧ Karartıcı & 1 & 2 & 3 & 4 & 5 & Ferahlatıcı \\
Estetik Değil & 1 & 2 & 3 & 5 & Estetik \\
Durağan & 1 & 2 & 3 & 4 & Hareketli \\
\hline
\end{tabular}


Çizelge 2. Meydan Parkı ve Atapark kullanıcılarının demografik yapılarına ilişkin sonuçlar

\begin{tabular}{|c|c|c|}
\hline & Meydan Parkı Kullanıcıları için Kişi sayısı (\% değer) & Atapark Kullanıcıları için Kişi sayısı (\% değer) \\
\hline \multicolumn{3}{|l|}{ CINSIYET DURUMU } \\
\hline Kadın & 45 & 48 \\
\hline Erkek & 55 & 52 \\
\hline TOPLAM & 100 & 100 \\
\hline \multicolumn{3}{|l|}{ MEDENI HAL } \\
\hline Evli & 50 & 49 \\
\hline Bekar & 50 & 51 \\
\hline TOPLAM & 100 & 100 \\
\hline \multicolumn{3}{|l|}{ YAŞ DURUMU } \\
\hline '15-24' & 28 & 30 \\
\hline '25-30’ & 20 & 24 \\
\hline ‘31-40’ & 17 & 9 \\
\hline ‘41-50’ & 20 & 14 \\
\hline ‘51-59’ & 9 & 11 \\
\hline ‘60 ve üzeri’ & 6 & 12 \\
\hline $\begin{array}{l}\text { TOPLAM } \\
\text { EĞiTIM DURUMLARI }\end{array}$ & 100 & 100 \\
\hline Okuryazar değil & 0 & 4 \\
\hline 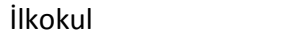 & 8 & 9 \\
\hline Ortaokul & 14 & 12 \\
\hline Lise & 38 & 23 \\
\hline Lisans & 29 & 35 \\
\hline Lisansüstü & 11 & 17 \\
\hline TOPLAM & 100 & 100 \\
\hline \multicolumn{3}{|l|}{ MESLEK DURUMLARI } \\
\hline Çalışmayan & 21 & 22 \\
\hline Öğrenci & 28 & 29 \\
\hline Serbest & 15 & 8 \\
\hline Emekli & 12 & 13 \\
\hline Özel ücretli & 12 & 10 \\
\hline Kamu ücretli & 12 & 18 \\
\hline TOPLAM & 100 & 100 \\
\hline & $\begin{array}{l}\text { Yürüyüş mesafesinde } \\
10 \text { dk. veya altı } \\
\text { Yürüyüş mesafesinde } \\
10-30 \text { dk. } \\
\text { Yürüyüş mesafesinde } \\
\text { değil araçla } \\
\text { @ Yürüyüş mesafesinde } \\
\text { değil şehir dışı }\end{array}$ & 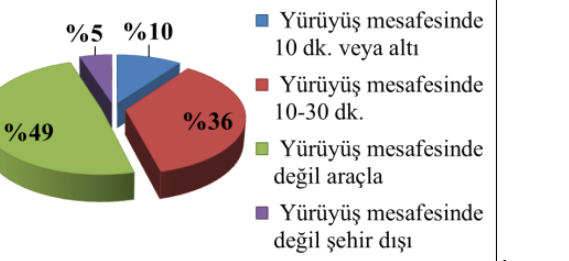 \\
\hline
\end{tabular}

Şekil 3. (a) Meydan Parkı'na geliş mesafeleri ve (b) Atapark'a geliş mesafeleri

"Dış mekanların aydınlatılmasında sizin için en çok önem taşıyan etken hangisidir?" diye sorulduğunda; 'Emniyetimi ve güvenliğimi sağlamalı' seçeneği Meydan Parkı için \%50 (Şekil 4a), Atapark için \%54 ile her iki park için de en çok tercih edilen seçenek olmuştur (Şekil 4b). $\mathrm{Bu}$ sonuçlar; kentsel açık yeşil alanlardan olan kent parklarının aydınlatılmasında dikkat edilmesi gereken üç önemli husustan olan emniyet ve güvenlik ile estetik olma ilkelerinin, park kullanıcıları tarafından doğrulandığını göstermektedir.
“Meydan Parkı/Atapark'a ne sıklıkla gelirsiniz?" diye sorulduğunda en yüksek değeri; Meydan Parkı için \%32 ile 'Haftada 2-3 defa' seçeneği (Şekil 5a), Atapark için ise \%28 ile'Ayda 1 defa' seçeneği almıştır (Şekil 5b). Yüzde değerlerine bakıldığında, Meydan Parkı'nı ziyaret eden kullanıcıların parkı bir geçiş mekanı işleviyle kullandığı, Atapark'ı ziyaret eden kullanıcıların ise parka daha uzun süreli bir etkinlik için geldikleri söylenebilir. 


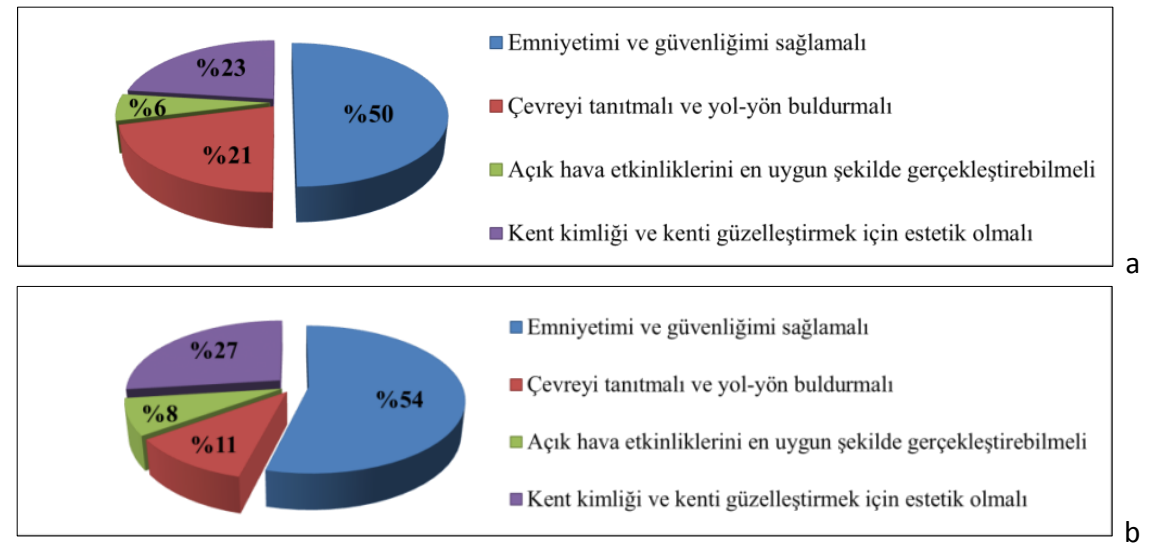

Şekil 4. (a) Meydan Parkı kullanıcıları için dış mekanların aydınlatıımasında en çok önem taşıyan etken ve (b) Atapark kullanıcıları için dış mekanların aydınlatılmasında en çok önem taşıyan etken
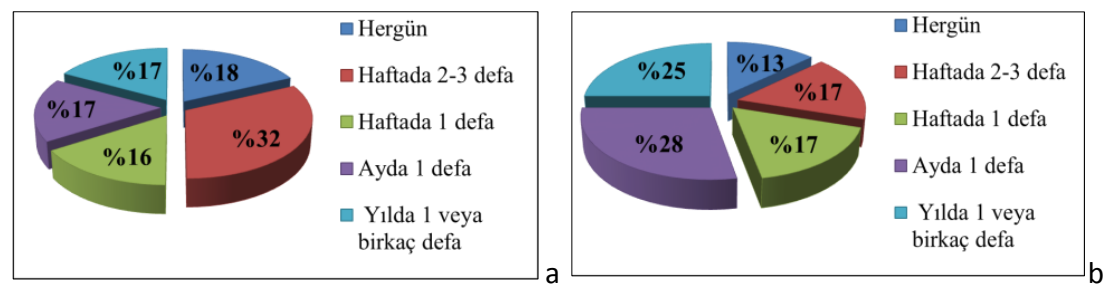

Şekil 5. (a) Meydan Parkı'nın ziyaret edilme sıklığı ve (b) Atapark'ın ziyaret edilme sıklığı

“Meydan Parkı/Atapark'ı günün hangi saatlerinde ziyaret edersiniz?" diye sorulduğunda; 'Öğle-akşam saatlerinde' cevabını verenler Meydan Parkı için \%66, Atapark için \%47'dir. 'Akşam saatlerinde' cevabını verenler ise Meydan Parkı için \%25, Atapark için \%45 olmuştur (Şekil $6 a, b) . B u$ yüzdeler günümüz modern teknolojileriyle

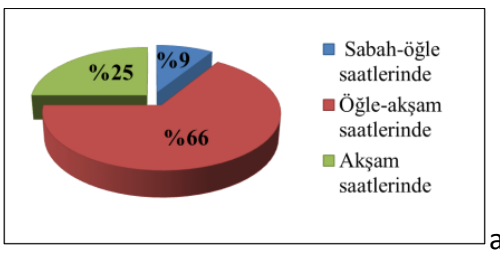

Şekil 6. (a) Meydan Parkı kullanıcılarının parkı ziyaret etme saatleri ve (b) Atapark kullanıcılarının parkı ziyaret etme saatleri

“Meydan Parkı/Atapark'ı daha çok hangi günlerde tercih edersiniz?" diye sorulduğunda; 'Hafta içi' cevabını verenler Meydan Parkı için \%48, Atapark için \%29'dur. 'Hafta sonu' cevabını verenler Meydan Parkı için \%50, Atapark için \%69'dur (Şekil 7a,b).Bu yüzdelere göre Meydan Parkı'nın ziyaret edilme durumu hafta içi ve hafta

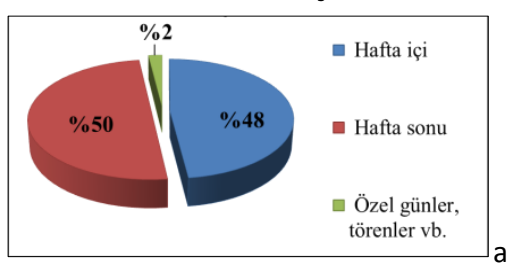

aydınlatılmış Meydan Parkı'nın, klasik aydınlatma tip ve teknikleriyle aydınlatılmış Atapark'a göre akşam saatlerinde kendi kullanıcıları tarafından daha az tercih edildiğini göstermesi bakımından çarpıcı bir sonuç ortaya koymaktadır.

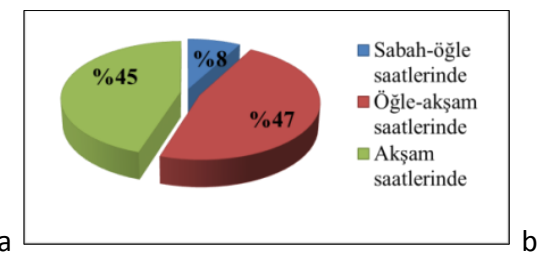

sonu için neredeyse eşit bir dağılım gösterirken, Atapark ise hafta sonları daha fazla tercih edilmektedir. Bu sonucun da, Meydan Parkı'nın bir geçiş mekanı olarak kullanıldığını, Atapark'ın ise daha uzun süreli bir etkinlik için ziyaret edildiğini kanıtladığı söylenebilir.

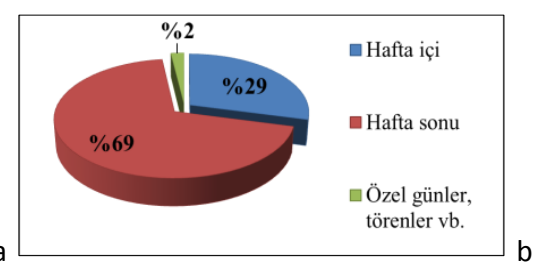

Şekil 7. (a) Meydan Parkı'nın günlere göre ziyaret edilme durumu ve (b) Atapark 'ın günlere göre ziyaret edilme durumu 
“Meydan Parkı/Atapark'ta ne kadar kalıyorsunuz?" diye sorulduğunda; ' 1 saatten az' cevabını verenler Meydan Parkı için \%38, Atapark için \%30'dur. '1-2 saat' cevabını verenler Meydan Parkı için \%38, Atapark için \%46'dır
(Şekil 8a,b). Diğer değerler Park kullanıcılarının parkları kullanım sürelerinin benzerliği,her iki parkın da sundukları rekreasyonel etkinlikler ve imkanların benzer olduğunu kanıtlamaktadır.
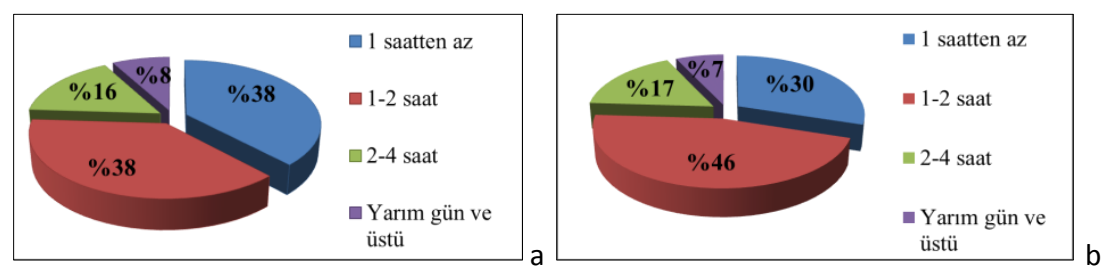

Şekil 8. (a) Meydan Parkı kullanııılarının parkta kalış süreleri ve (b) Atapark kullanıcılarının parkta kalış süreleri

"Meydan Parkı/Atapark'a kiminle geldiniz?" diye sorulduğunda; 'Arkadaşlarımla' cevabını verenler ise Meydan Parkı için \%50, Atapark için \%47 olmuştur (Şekil 9a,b). Bu yüzdelere göre, her iki park için de 'Arkadaşlarımla' cevabını verenlerin neredeyse eşit

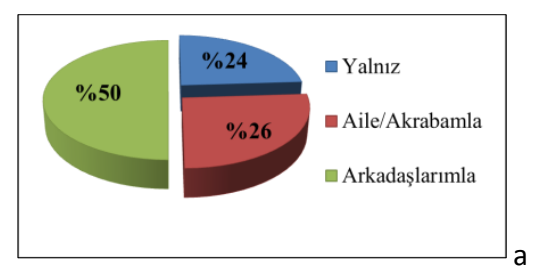

Şekil 9. (a) Meydan Parkı'nı ziyaret eden kullanıcıların parka geliş tercihleri ve (b) Atapark'ı ziyaret eden kullanıcıların parka geliş tercihleri

"Meydan Parkı/Atapark'ı ne amaçla ziyaret edersiniz?" diye sorulduğunda; 'Oturma-dinlenme için' cevabını verenler Meydan Parkı için \%37, Atapark için \%51 ile en yüksek değerlere sahip olmuşlardır (Şekil 10a,b). Bu yüzdelere göre parka 'Oturma-dinlenme' amacıyla gelme,
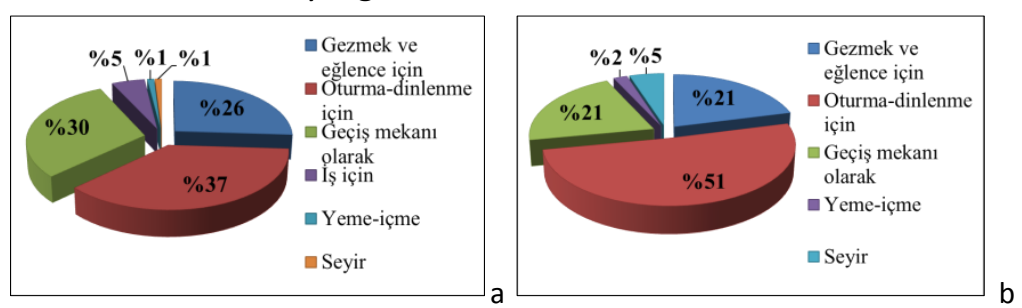

Şekil 10. (a) Meydan Parkı kullanıcılarının parka geliş amaçları ve (b) Atapark kullanıcılarının parka geliş amaçları

“Meydan Parkı/Atapark'ta sizi en çok etkileyen öğe nedir?" diye sorulduğunda verilen yanıtlara ilişkin yüzde değerleri Şekil 11a ve Şekil 11b'de görülmektedir. Meydan Parkı'nda çocuk oyun alanı bulunmamaktadır. Fakat alan çalışmalarında ışık ve su gösterilerinin olduğu bölümde daha çok çocukların vakit geçirdiği, ebeveynlerin çocuklarını buradaki su oyunlarına getirdiği gözlenmiştir. Bu nedenle kullanıcıların Meydan Parkı için bu alanı bir olması ve diğer seçeneklerin aldıkları değerlerin de paralellik göstermesi; parkların benzer etkileri ve imkanları olduğunu ve bu doğrultuda tercih edilme durumlarının da benzer olduğunu göstermektedir.

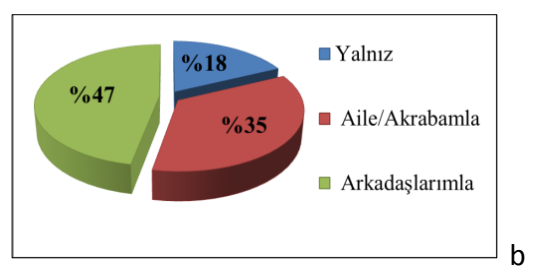

her iki park kullanıcıları için de en büyük yüzdeye sahip olmakla birlikte; diğer seçeneklerin sıralaması da paralel çıkmıştır. Bu durum parkların sundukları rekreasyonel etkinlik ve imkanların benzerlik gösterdiğinin bir kanıtıdır.

çocuk oyun alanı gibi değerlendirildiği söylenebilir. Bu yüzdelere göre, Meydan Parkı'nda en çok etkilenilen öğe olarak 1.sırada 'Su gösterileri-ışık gösterileri', 2.sırada 'Oturma alanları' ve 3.sırada 'Yeşil alanlar' yer almaktadır. Atapark için ise 1.sırada 'Yeşil alanlar', 2.sırada 'Oturma alanları ve çocuk oyun alanı-eğlence, ve 3.sırada 'Kütüphane, ibadethaneler vb.' yer almaktadır. 

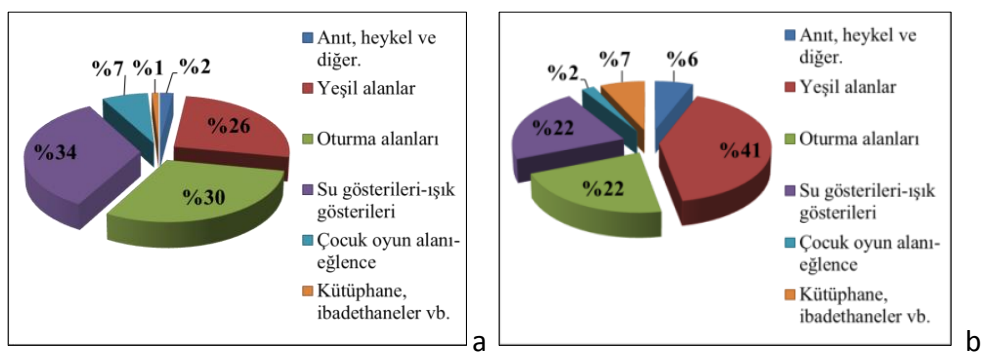

Şekil 11. (a) Meydan Parkı kullanıcılarının parkta en çok etkilendikleri öğe ve (b) Atapark kullanııılarının parkta en çok etkilendikleri öğe

“Meydan Parkı/Atapark'ta kendinizi güvende hissediyor musunuz?" diye sorulduğunda; 'Evet' cevabını verenler Meydan Parkı için \%75, Atapark için \%76'dır. 'Hayır' cevabını verenler ise Meydan Parkı için \%25, Atapark için \%24'tür (Şekil 12a,b). Bu yüzdelere göre her iki park için de kullanıcıların büyük kısmının parklarda kendilerini güvende hissettikleri görülmektedir. Bu sonuç, günümüz modern aydınlatma tip ve tekniklerinin kullanıldığı Meydan Parkı ve klasik aydınlatma tip ve teknikleriyle aydınlatılan Atapark için parkların kullanıcıları açısından bir fark oluşturmadığını göstermektedir. Bu sonuçla, güvenlik sağlama konusunda modern ve klasik aydınlatmanın birbirine bir üstünlük sağlayamadığı görülmüştür.
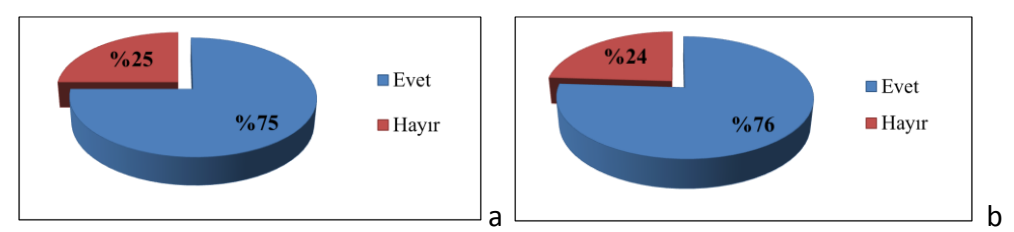

Şekil 12. (a) Meydan Parkı kullanıcılarının parkta kendilerini güvende hissetme durumu ve (b) Atapark ziyaretçilerinin parkta kendilerini güvende hissetme durumu

“Sizce Meydan Parkı/Atapark'ı güvensiz kılan etmenler nelerdir?" diye sorulduğunda; verilen yanıtlara ilişkin yüzde değerleri Şekil 13a ve Şekil 13b'de görülmektedir.
Bu yüzdelere göre her iki parkın kullanıcıları için de parkları güvensiz bulanların büyük bir çoğunluğu 1.sırada 'İnsan yoğunluğu' cevabını vermişlerdir.
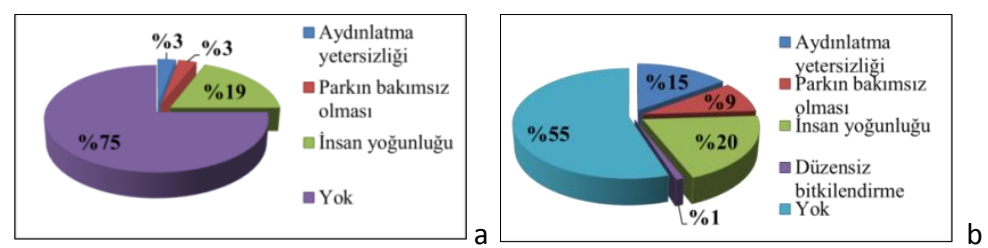

Şekil 13. (a) Meydan Parkı kullanıcıları için parkı güvensiz kılan etmenler ve (b) Atapark kullanıcıları için parkı güvensiz kılan etmenler

“Meydan Parkı/Atapark'taki aydınlatma gözlerinizde kamaşmaya neden oluyor mu?” diye sorulduğunda; 'Evet oluyor' cevabını verenler Meydan Parkı için \%20, Atapark için \%23'tür. 'Hayır olmuyor' cevabını verenler ise
Meydan Parkı için \%80, Atapark için \%77'dir (Şekil 14a,b). Bu sonuç da, modern ve klasik karşıtlığıyla aydınlatılmış parklardaki aydınlatma elemanlarının kullanıcıları açısından farklı bulunmadığının kanıtıdır.
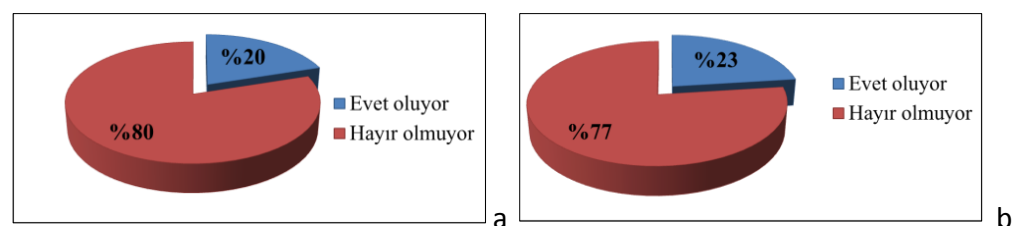

Şekil 14. (a) Meydan Parkı kullanıcıları parktaki aydınlatmanın kamaşmaya neden olma durumu ve (b) Atapark kullanıcıları için parktaki aydınlatmanın kamaşmaya neden olma durumu 
"Meydan Parkı/Atapark'taki aydınlatmayı nası buluyorsunuz?" diye sorulduğunda; 'Yeterli' cevabını verenler Meydan Parkı için \%65, Atapark için \%41'dir. 'Yetersiz' cevabını verenler ise Meydan Parkı için \%35,
Atapark için \%59'dur (Şekil 15a,b). Bu yüzdeler, Atapark kullanıcılarının parktaki aydınlatmayı yetersiz bulduklarını göstermektedir.
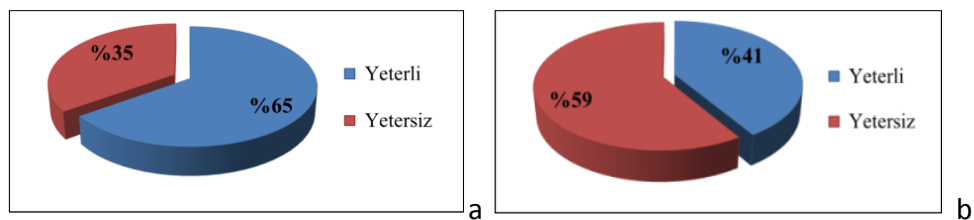

Şekil 15. (a) Meydan Parkı kullanıcıları parktaki aydınlatmanın yeterlilik durumu ve (b) Atapark kullanıcıları için parktaki aydınlatmanın yeterlilik durumu

“Meydan Parkı/Atapark'taki aydınlatma miktarının yeterli olduğu alanlar hangileridir?" diye sorulduğunda; verilen yanıtlara ilişkin yüzde değerleri Şekil 16a ve Şekil 16b'de görülmektedir. Bu değerlere göre, parklardaki aydınlatma miktarının yeterli bulunduğu alanlar Meydan Parkı ve Atapark için 1.sırada 'Su öğeleri' olarak belirlenmiştir.
Sonuçlar; her iki park için de paralellik göstermekle birlikte, parkların modern ve klasik aydınlatma elemanlarıyla aydınlatılmalarının etkinlik alanları açısından kullanıcıları için farklılık göstermediğinin ve bu modern klasik zıtlığının birbirine bir üstünlük sağlayamadığının bir kanıtıdır.
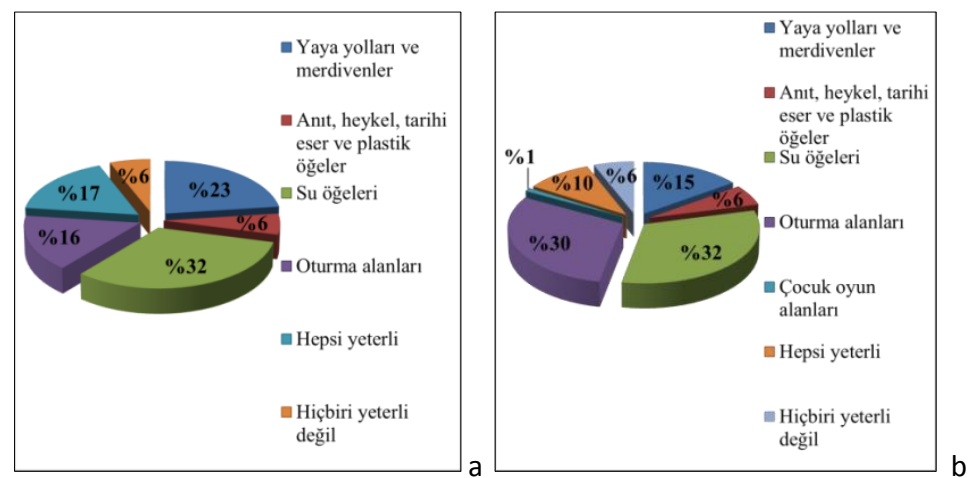

Şekil 16. (a) Meydan Parkı kullanıcıları için parktaki aydınlatmanın yeterli olduğu alanlar ve (b) Atapark kullanıcıları için parktaki aydınlatmanın yeterli olduğu alanlar

“Meydan Parkı/Atapark'taki aydınlatma miktarının yetersiz olduğu alanlar hangileridir?" diye sorulduğunda; verilen yanıtlara ilişkin yüzde değerleri Şekil 17a ve Şekil 17b'de görülmektedir. Bu değerlere göre, parklardaki aydınlatma miktarının yetersiz bulunduğu alanlardan Meydan Parkı için 1.sırada 'Anıt, heykel, tarihi eser ve plastik objeler' yer almaktadır. Atapark için ise, 1.sırada 'Çocuk oyun alanları' yer almaktadır.
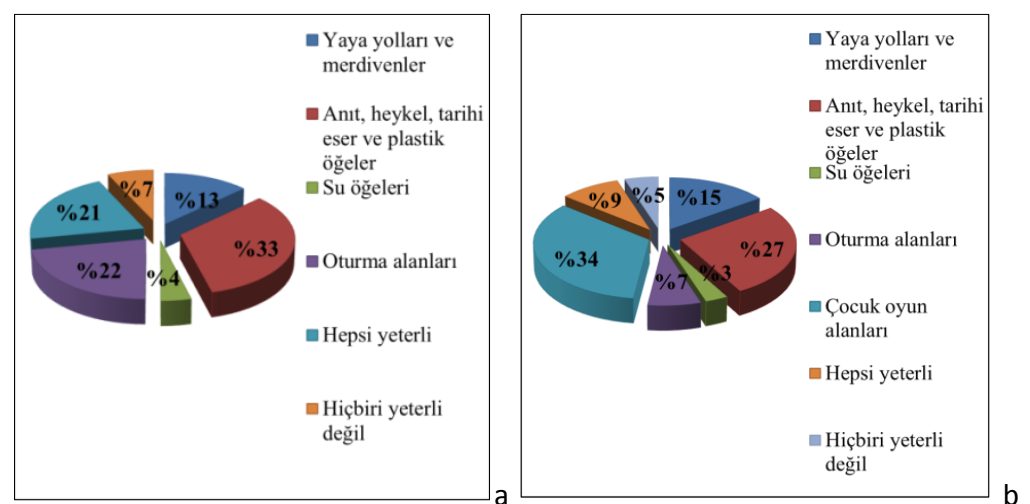

Şekil 17. (a) Meydan Parkı kullanıııları için parktaki aydınlatmanın yetersiz olduğu alanlar ve (b) Atapark kullanıııları için parktaki aydınlatmanın yetersiz olduğu alanlar 
“Meydan Parkı/Atapark'taki genel aydınlatmayı nasıl tanımlarsınız?" diye sorulduğunda ise; Meydan Parkı için \%57 ile 'Yeterli-normal', Atapark için \%62 ile'Rastgelesıradan' seçenekleri en yüksek değerlere sahip olmuştur.
Bu değerlere göre Meydan Park'ı kullanıcıları parkın aydınlatmasını normal olarak tanımlarken, Atapark kullanıcıları ise parkın aydınlatmasını sıradan olarak tanımlamaktadır (Şekil 18a,b).
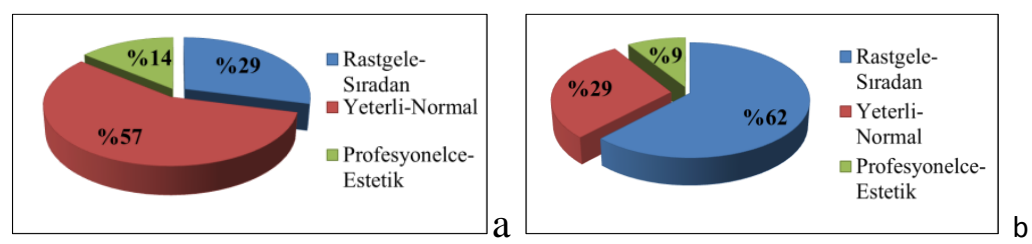

Şekil 18. (a) Meydan Parkı kullanıcıları için parkın aydınlatmasının tanımlanması ve (b) Atapark kullanıcıları için parkın aydınlatmasının tanımlanması

Ankette kullanıcıları tanımaya ve kullanımları belirlemeye yönelik sorular sorulduktan sonra her iki parkın aydınlatılmış mekan bileşen ve öğelerinin (yaya yolları ve merdivenler, oturma alanları, yapı çevreleri, çocuk oyun alanları, su elemanları, anıt, heykel, tarihi eser ve plastik objeler ve bitkisel materyalin) kullanıcılar tarafından anlamsal açıdan değerlendirilmesi ve karşılaştırmaların yapılabilmesi için "anlamsal farklılaşım ölçeği" kullanılmıştır. Her iki park için aydınlatılmış mekan bileşen ve öğelerinin anlamsal açıdan değerlendirilmesinde sıfat çiftlerinin aldıkları ortalama puanlar Şekil 19'da verilmiştir. Buna göre;

Aydınlatılmış yaya yolları ve merdivenlerin anlamsal açıdan değerlendirilmesinde sıfat çiftlerinin aldığı ortalama puanlar; Meydan Parkı'nda 'Durağan-hareketli' sıfat çifti 3.60 ile en yüksek, 'Sıkıcı-ilginç' sıfat çifti 3.32 ile en düşük değerler olmuştur. Atapark'ta'Yorucudinlendirici' sıfat çifti 2.98 ile en yüksek, 'Durağanhareketli' sıfat çifti ise 2.57 ile en düşük ortalamaya sahip olmuştur. Diğer sonuçlara bakıldığında Meydan Parkı'na ait değerlerin kısmen 3 ile 3.50 arasında olduğu görülmektedir. Atapark'ta ise nötr ve üstünde hiçbir değer bulunmadığı görülmektedir. Buna göre, Atapark kullanıcıları parkın yürüyüş yolları ve merdivenlerinin aydınlatılmasını; sıkıcı, tedirgin edici, yorucu, etkisiz, iç karartıcı, estetik değil ve durağan olarak değerlendirdiği söylenebilir.

Aydınlatılmış oturma alanlarının anlamsal açıdan değerlendirilmesinde sıfat çiftlerinin aldığı ortalama puanlar; Meydan Parkı'nda 'Tedirgin edici-güven verici' sıfat çifti 3.46 ile en yüksek, 'Sıkıcı-ilginç' sıfat çifti 3.21 ile en düşük değerler olmuştur. Atapark'ta 'Yorucudinlendirici' sıfat çifti 3.34 ile en yüksek, 'Estetik değilestetik' sıfat çifti 2.92 ile en düşük ortalamaya sahip değerler olmuştur. Diğer sonuçlara bakıldığında Meydan Parkı'na ait değerlerin 3 ile 3.50 arasında olduğu görülmektedir. Bu sonuçlar; bu etkinlik alanlarındaki aydınlatmanın kullanıcılar tarafından çok da nitelikli bulunmadığını göstermektedir. Atapark'ın 'sıkıcı-ilginç' ve 'estetik değil-estetik' sıfat çiftleri için aldığı değerler nötr değerin altındadır.

Meydan Parkı'nda aydınlatılmış yapı çevrelerinin anlamsal açıdan değerlendirilmesinde sıfat çiftlerinin aldığı ortalama puanlar; 'Tedirgin edici-güven verici' sıfat çifti ile 'Yorucu-dinlendirici' sıfat çifti 3.17 ile en yüksek, 'Sıkıcı-ilginç' sıfat çifti 3.02 ile en düşük değerler olmuştur. Diğer sonuçlara bakıldığında değerlerin nötr değerine yakın olduğu ve bu alanların aydınlatmasının kullanıcıları tatmin etmediği görülmektedir.

Atapark'ta aydınlatılmış çocuk oyun alanlarının anlamsal açıdan değerlendirilmesinde sıfat çiftlerinin aldığı ortalama puanlar; 'Yorucu-dinlendirici' sıfat çifti 2.27 ile en yüksek, 'Durağan-hareketli' sıfat çifti 1.96 ile en düşük değer olmuştur. Diğer sonuçlara bakıldığında değerlerin nötr değerinin altında olduğu ve bu alanların aydınlatılmasının kullanıcılar tarafından sıkıcı, tedirgin edici, yorucu, etkisiz, iç karartıcı, estetik değil ve durağan şeklinde nitelendirildiği söylenebilir. 

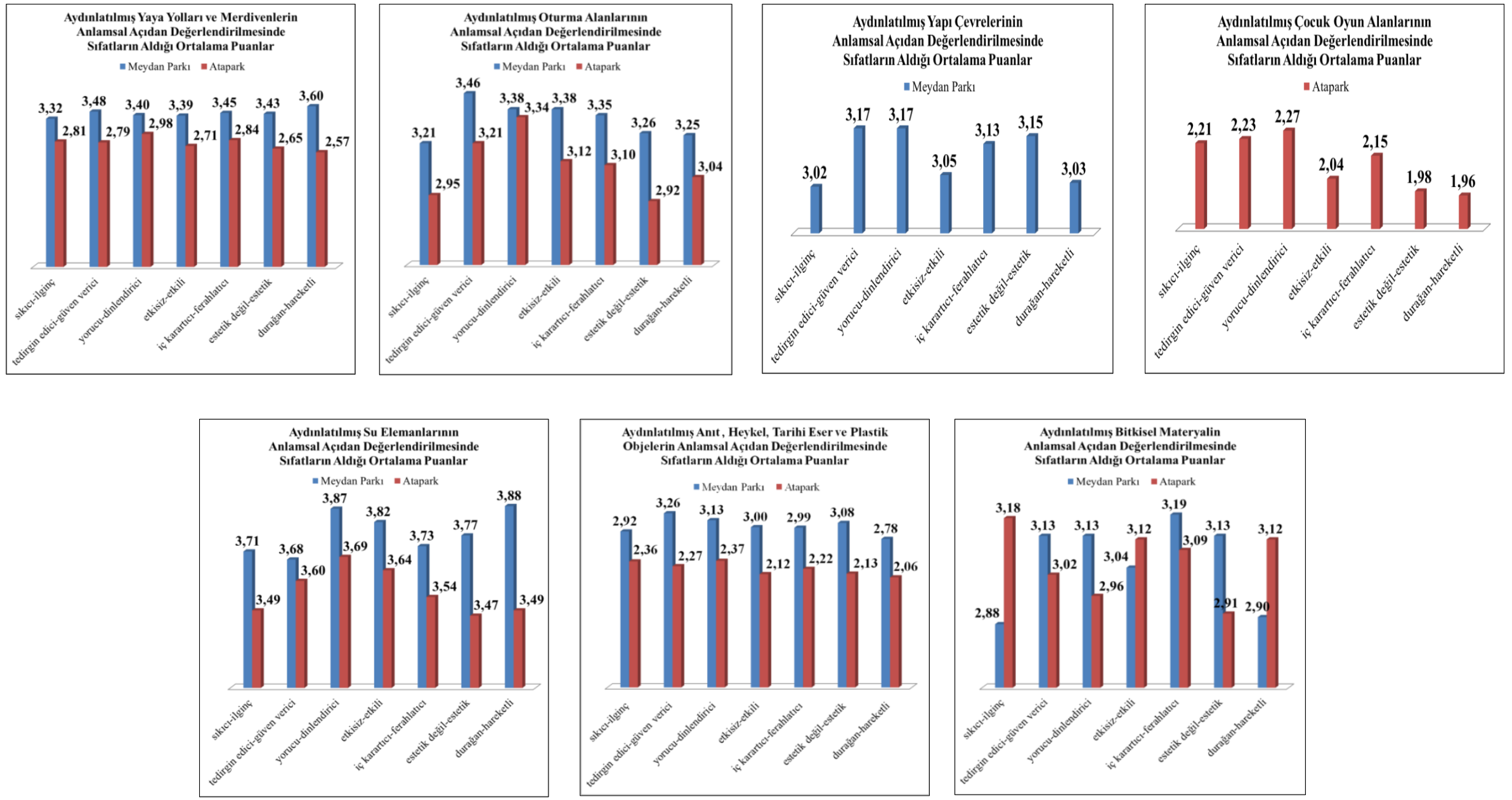

Şekil 19. Meydan Parkı ve Atapark'ın mekan bileşen ve öğelerinin kendi kullanıcıları tarafından anlamsal açıdan değerlendirilmesi 
Aydınlatılmış su elemanlarının anlamsal açıdan değerlendirilmesinde sıfat çiftlerinin aldığı ortalama puanlar; Meydan Parkı'nda 'Durağan-hareketli' sıfat çifti 3.88 ile en yüksek, 'Tedirgin edici-güven verici' sıfat çifti 3.68 ile en düşük değerler olmuştur. Atapark'ta 'Yorucudinlendirici' sıfat çifti 3.69 ile en yüksek, 'Estetik değilestetik' sıfat çifti 3.47 ile en düşük ortalamaya sahip değerler olmuştur. Diğer sonuçlara bakıldığında değerlerin kısmen 3.50 ile 4.00 arasında olduğu görülmektedir. Bu sonuçlar; her iki park için de bu etkinlik alanlarındaki aydınlatmanın kullanıcılar tarafından diğer alanlara göre daha nitelikli bulunduğunu göstermektedir.

Aydınlatılmış anıt, heykel, tarihi eserler ve plastik objelerin anlamsal açıdan değerlendirilmesinde sıfat çiftlerinin aldığı ortalama puanlar; Meydan Parkı'nda 'Tedirgin edici-güven verici' sıfat çifti 3.26 ile en yüksek, 'Durağan-haraketli' sıfat çifti 2.78 ile en düşük değerler olmuştur. Atapark'ta 'Yorucu-dinlendirici' sıfat çifti 2.37 ile en yüksek, 'Durağan-hareketli' sıfat çifti 2.06 ile en düşük ortalamaya sahip değerler olmuştur. Diğer sonuçlara göre; Meydan Parkı kullanıııları anıt, heykel, tarihi eser ve plastik objelerin aydınlatılmasını durağan olarak nitelendirirken, diğer sıfat çiftlerini nötr değerine yakın olarak değerlendirmektedir. Atapark kullanııları ise anıt, heykel, tarihi eser ve plastik objelerin aydınlatılmasını; sıkıcı, tedirgin edici, yorucu, etkisiz, iç karartıcı, estetik değil ve durağan olarak değerlendirmektedir.

Aydınlatılmış bitkisel materyalin anlamsal açıdan değerlendirilmesinde sıfat çiftlerinin aldığı ortalama puanlar; Meydan Parkı'nda 'lç karartıcı-ferahlatıcı' sıfat çifti 3.19 ile en yüksek, 'Sıkıcı-ilginç' sıfat çifti 2.88 ile en düşük değerler olmuştur. Atapark'ta 'Sıkıcı-ilginç' sıfat çifti 3.18 ile en yüksek, 'Estetik değil-estetik' sıfat çifti 2.91 ile en düşük ortalamaya sahip değerler olmuştur. Diğer sonuçlara bakıldığında; Meydan Parkı için büyük çoğunlukla nötre yakın ve altında değerler aldığı ve aydınlatmanın sıkıcı, ve durağan olarak nitelendirildiği görülmektedir. Atapark için ise benzer şekilde nötre yakın ve altında değerler söz konusu olmakla birlikte, Meydan Parkı'na göre daha yüksek ortalamalar ilginç, etkili ve hareketli sıfatları için olmuştur.

Sonuç olarak Meydan Parkı ve Atapark için etkinlik alanlarına göre sıfatların aldığı ortalama değerler karşılaştırmalı olarak Şekil 20'de verilmiştir. Grafiğe bakıldığında sıfat çiftlerinin aldığı ortalama değerlerin, Meydan Parkı'nda Atapark'a göre nispeten daha yüksek çıktığı görülmektedir. Ancak en yüksek 3-3,5 arasında olan bu değerlerin 1 ile 5 değer aralığına sahip Likert skalasında çok tatmin edici olmadığı açıktır.

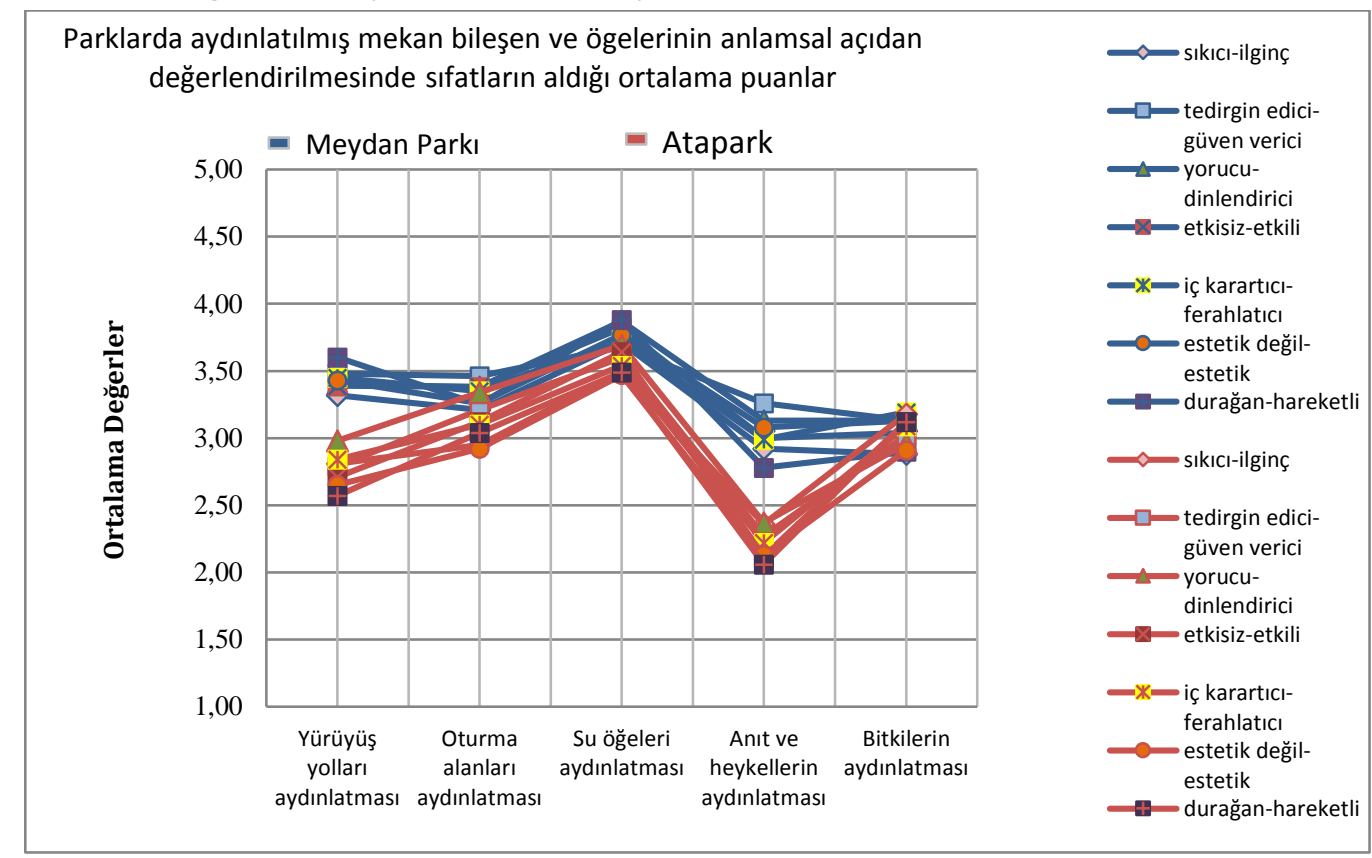

Şekil 20. Meydan Parkı ve Atapark için aydınlatıımış mekan bileşen ve öğelerinin kendi kullanıııları tarafından anlamsal açıdan değerlendirilmesi 


\section{TARTIŞMA VE SONUÇ}

Aydınlatma fiziksel, biyolojik, teknik, ekonomik, ekolojik vb. birçok açıdan ele alınması gereken çok bileşenli bir konudur. Ancak birçok konuda planlama/tasarım süreçlerinin gerektiği gibi ele alınmaması aydınlatma konusunda da görülmekte; bu durum teknik, psikolojik, estetik, ekonomik vb. birçok yanlış uygulamanın ortaya çıkmasına sebep olmaktadır. Bu yanlış uygulamalar da daha büyük ölçeklerde(örn. kentlerde ortaya çıkan ışık kirliği, kazalar ve suç oranlarındaki artış vb.) sorunlara neden olabilmektedir.

Günümüzde aydınlatma tasarımı konusunda en büyük sorun; Meydan Parkı ve Atapark örneklerinde de doğrulandığı üzere plansız uygulamalardır. Bu nedenle aydınlatma tasarımları çoğu kez estetik bir görüntü oluşturma gayretinden ileri gidememektedir. Keza yapılan değerlendirmelerde modern ve geleneksel tip ve teknikleri barındıran iki ayrı park için birbirine üstünlük sağlayacak bir fark ortaya çıkmamış, modernlik üstünlük sağlayıcı bir unsur olamamıştır. Nitekim anlamsal farklılaşıma ilişkin değerlendirmelerden bitkisel metaryalin aydınlatılmasına ilişkin sonuçlara bakıldığında; daha geleneksel tip ve tekniklere sahip Atapark, Meydan Parkı'na göre daha ilginç, etkili ve hareketli bulunmuştur. Bu durum doğru aydınlatma tasarımı kavramına işaret etmektedir. Bu nedenle aydınlatma uygulama projeleri hayata geçirilmeden önce Sözen (2003)'in ifade ettiği ön tasarım, tasarım ve uygulama projesi olarak üç aşamanın gerektiği gibi ele alınması, doğru aydınlatma tasarımlarının uygulamaya konulması açısından önemlidir. Bununla birlikte Alper Turgut ve Yılmaz (2006) bu durumun sonradan oluşabilecek uyumsuzluk ve olumsuzlukların engellenmesi açısından önemli olduğunu belirterek, aydınlatmayı belirleyecek etkenler olarak; aydınlatma amacının niteliği, aydınlatılacak ortamın koşulları, nesnelerin özellikleri, aydınlatma türü, aydınlatma elemanlarının teknik ve fiziksel özellikleri gibi faktörleri sıralamıştır.

Aydınlatma konusu çalışmada da ele alındığı üzere, mekan ve öğelerin aydınlatılması kapsamında değerlendirildiğinde, tasarımcının aydınlatmaya başlamadan önce alanla ilgili kararlar vermesi ve bu kararlar doğrultusunda aydınlatma tasarımı yapması gerekir. Tasarımcının aydınlatma ile öncelikle alan veya obje üzerinde ne tür bir yaklaşım sergileyeceğine karar vermesi gerekir. Ancak, burada dikkat edilmesi gereken öncelikli amaç Şahin (2012)'in de ifade ettiği gibi farklı görevleri yerine getirebilecek, mekan ve nesneleri algılayabilecek görsel koşulların, yani görsel konfor koşullarının sağlanmasıdır. Bunun yanı sıra Manav (2005)'ın da altını çizdiği gibi kaliteli aydınlatma fizyolojik gereksinimlerle birlikte psikolojik gereksinimleri de karşılamalı ve ışığın doğrultusu, aydınlığın düzgünlüğü, renk sıcaklığı gibi özelliklerin kullanıcılar üzerindeki etkilerini bir tasarım problemi olarak ele almalıdır. Bu bağlamda çalışma, bu etkilerin sorgulandığı bir pilot çalışma özelliği taşımaktadır.

Doğru aydınlatma tasarımı için alan kullanımları ortaya konulmalı ve bu kullanımlarla uyumlu özel kriterler paralelinde planlama ve tasarımlar yapılmalıdır. Bu nedenle aydınlatma tasarımları parkların tasarlanmasına aktif olarak görev yapan peyzaj mimarları tarafından yapılmalıdır. Uzmanlıkları gereği elektrik mühendisi, mimar gibi ilgili meslek disiplinlerinden kişiler ile de koordineli bir çalışma yürütmek doğru bir yaklaşım olacaktır.

\section{TEŞEKKÜR}

Bu çalışma, Doç. Dr. Banu Çiçek KURDOĞLU danışmanlığında Tuğba ÜSTÜN TOPAL'ın KTÜ Fen Bilimleri Enstitüsü'nde hazırlamış olduğu “Kentsel Park Aydınlatmalarının Kullanıcı Açısından Değerlendirilmesi: Trabzon Kenti Meydan Parkı ve Atapark Örnekleri” başlıklı Yüksek Lisans Tezi'nden üretilmiştir.

\section{KAYNAKLAR}

Acar C, Demirbaş E, Dinçer P, Acar H (2003) Anlamsal Farklılaşım Tekniğinin Bitki Kompozisyonu Örneklerinde Değerlendirilmesi, Süleyman Demirel Üniversitesi Orman Fakültesi Dergisi Seri: A, Sayı: 1, 15-28.

Acar EE (2008) Peyzaj Aydınlatmasının Algı Üzerine Etkilerinin Düzce Kenti Örneğinde İrdelenmesi, Yüksek Lisans Tezi, Düzce Üniversitesi, Fen Bilimleri Enstitüsü, Peyzaj Mimarlığı Anabilim Dalı, Düzce.

Albayrak S (2000) Gülhane, Yıldız ve Emirgan Parklarının Kent Parkı İ̧̧levi Açısından İrdelenmesi, Yüksek Lisans Tezi, iтÜ, Fen Bilimleri Enstitüsü, İstanbul. 
Alper Turgut H, Yılmaz S (2006) Peyzaj Mimarlığında Yapay Aydınlatma ve Estetik Kaygılar, Atatürk Üniversitesi Güzel Sanatlar Fakültesi Sanat Dergisi, 9: 46-56.

Anonim (1992) İstanbul Kentsel Tasarım Kılavuzu. Yıldız Teknik Üniversitesi Mimarlık Fakültesi Kentsel Tasarım Çalışma Grubu, İstanbul.

Büyükbıçakçı Z (2010)Bilgisayar Destekli Aydınlatma Programlarının Aydınlatma Tekniğindeki Yeri ve Önemi, Yüksek Lisans Tezi, Marmara Üniversitesi, Fen Bilimleri Enstitüsü, Elektrik Eğitimi Anabilim Dalı, İstanbul.

Çetindağ K (2007) Işık ve Renk Kullanımının Mekan Algılamasına Etkisi Üzerine Bir Araştırma, (Sultanahmet Meydanı Örneği), Yüksek Lisans Tezi, İstanbul Üniversitesi, Fen Bilimleri Enstitüsü, İstanbul.

Dedeoğlu i (2006) Kentsel Yeşil Alanların Gece Kullanımında Dış Aydınlatmanın Önemi ve Yöntemi: Gülhane Parkı Örneği, Fen Bilimleri Enstitüsü, Bahçeşehir Üniversitesi, Çevre Tasarımı Yüksek Lisans Programı, İstanbul.

Kalıpsız A (1981) İstatistik Yöntemler, i.Ü. Orman Fakültesi, Yayın No: 2837, O. F. Yayın No: 294, İstanbul.

Kwok K (1979) Semantic Evaluation of Perceived Environment:A CrossCultural Replication, Man-Environment Systems 9:243-249.

Manav B (2005) Ofislerde aydınlık Düzeyi, Parıltı Farkı ve Renk Sıcaklığının Görsel Konfor Koşullarına Etkisi, Doktora Tezi, İstanbul Teknik Üniversitesi, Fen Bilimleri Enstitüsü, İstanbul.

Onuk NT (2008) Kentsel Dış Mekanların Aydınlatılması Kapsamında Işık Kirliliğinin İrdelenmesi, Yüksek Lisans Tezi, İstanbul Teknik Üniversitesi, Fen Bilimleri Estitüsü, Peyzaj Mimarlığı Anabilim Dalı, İstanbul.
Osgood CE, May WH, Miron MS (1975) Cross-cultural Universals of Affective Meaning. Urbana: Universityof Illinois Press.

Öztürk LD (1992) Kent Aydınlatma İlkeleri, Yıldız Teknik Üniversitesi Yayınları No: 247, Mimarlık Fakültesi Yayınları No: MF-MiM 92.036, Baskı İşliği, İstanbul.

Sakıcı Ç, Var M (2014) A Visual Perception Effect Assessment of Some Large and Broad-Leaved Trees Under Different Lighting Arrangements, Journal Architectural Science Review 57(2): 139146.

Sözen MŞ (2000) Aydınlatma ve Kent Güzelleştirme. 3. Ulusal Aydınlatma Kongresi Bildiriler Kitabı. Aydınlatma Türk Milli Komitesi, iтÜ Elektrik-Elektronik Fakültesi, İstanbul. 116-120.

Sözen MŞ (2003) Aydınlatma Tasarımında Mimarın ve Elektrik Mühendisinin Rolü, II. Ulusal Aydınlatma Sempozyumu ve Sergisi, 8-10 Kasım, Diyarbakır.

Sözen MŞ, Geçioğlu E (2007) Kent Aydınlatmada Reklam Öğeleri, 4. Ulusal Aydınlatma Sempozyumu, 13-15 Aralık, İzmir.

Şahin D (2012) Aydınlatma Tasarımının Kullanıc Üzerindeki Fizyolojik ve Psikolojik Etkileri Açısından İncelenmesi, Yüksek Lisans Tezi, İstanbul Teknik Üniversitesi, Fen Bilimleri Enstitüsü, Mimarlık Anabilim Dalı, Çevre Kontrolü ve Yapı Teknolojisi Programı, İstanbul.

Üstün T (2014) Kentsel Park Aydınlatmalarının Kullanıcı Açısından Değerlendirilmesi: Trabzon Kenti Meydan Parkı ve Atapark Örnekleri. Karadeniz Teknik Üniversitesi, Fen Bilimleri Enstitüsü, Peyzaj Mimarlı̆ıı Anabilim Dalı, Trabzon. 